\title{
EMPLOYEE PERFORMANCE, LEADERSHIP STYLE AND EMOTIONAL INTELLIGENCE: AN EXPLORATORY STUDY IN A SOUTH AFRICAN PARASTATAL
}

\author{
BA Hayward, TL Amos and J Baxter, Rhodes University, Grahamstown, South Africa
}

Purpose: The purpose of this research is to explore the relationship between employee performance, leadership style and emotional intelligence in the context of a South African parastatal.

Problem Investigated: There is a lack of literature and empirical research on the type of leadership required to achieve high levels of employee performance within South African parastatals.

Methodology: The Multifactor Leadership Questionnaire (MLQ) was used to determine leadership style, while the Emotional Competency Profiler (ECP) was used to determine the emotional intelligence of the sample of leaders. Employee performance data was provided by the parastatal, based on their performance management system. Data was analysed using correlation analysis, multiple regression analysis, the standard regression ANOVA/F-test, t-tests and Cronbach alpha reliability coefficient.

Findings: The findings of the research show that the ECP is a reliable measure of emotional intelligence and that while the MLQ is a reliable measure of transformational leadership, it is not a reliable measure of transactional leadership. The results of the correlation analysis show a positive significant relationship between emotional intelligence and transformational leadership and a negative significant relationship between employee performance and emotional intelligence. The results of regressing employee performance on emotional intelligence and transformational leadership show that emotional intelligence and transformational leadership have no significant effect on employee performance. The results of the regression models of the research could be biased by the lack of variance in employee performance data.

Value of the Research: The value of the research lies in it confirming the MLQ as a reliable measure of transformational leadership and the ECP as a reliable measure of emotional intelligence. The finding of a positive significant relationship between emotional intelligence and transformational leadership is a valuable contribution to the literature.

Conclusion: Although a positive significant relationship between emotional intelligence and transformational leadership was found, there is a need for further research to determine the type of leadership best suited to achieve high levels of employee performance within the parastatal.

Key words and phrases: Employee performance, emotional intelligence, transactional leadership, transformational leadership, parastatal.

\section{INTRODUCTION}

A parastatal is defined as an organisation or agency owned, or controlled wholly or partly by the government (Cullen, Gilmour \& Holmes, 2005). The South African government's strong role in shaping the economy resulted in a large number of parastatals, or state corporations, being established in the 1920s. Their primary goal was to strengthen import-substitution industries and to expand the local economy (Nwankwo \& Richards, 2001). Parastatals had to be set up to fill such vacuums especially in areas like steel production, fertilizer manufacturing, air transport and other public utilities, education and health services (Nwankwo \& Richards, 2001). Such state-owned companies though rarely make a reasonable return on investment and historically have not performed efficiently enough to ensure their existence without continued state subsidy (Adam, Cavendish, \& Mistry, 1992 and Nwankwo \& Richards, 2001).

With leadership being regarded as instrumental in determining "... the returns that organisations realise from their human capital, or human resources" (Charlton, 1993:9), the poor performance of 
parastatals raises questions as to the type of leadership required to achieve the levels of employee performance necessary for the overall performance of parastatals. The aim of this research is to explore the relationship between employee performance, leadership style and emotional intelligence in the context of a South African parastatal. The particular parastatal was chosen on the basis of it being internationally recognised for its achievements in providing a reliable and affordable service in support of Government's social and economic objectives (Personal Communication, 2004)

The paper begins with the theoretical background to the study where literature and empirical research relating to the type of leadership associated with employee performance is reviewed. The section considers the leadership constructs of transactional and transformational leadership as well as emotional intelligence as a requirement of effective leadership. Following the theoretical background is the methodology section which identifies the research hypotheses, presents the research population and sample, describes the research instruments used and outlines the data collection process and analysis methods used. The findings of the research are then presented followed by a discussion and a consideration of the limitations of the research, suggestions for further research and managerial implications.

\section{THEORETICAL BACKGROUND}

In the search for the type of leadership that will achieve the levels of employee performance necessary for the overall performance of organisations it is clear that there are many ways of understanding leadership. For purposes of this study, the most useful are two broad views of leadership - the traditional view of transactional leadership, involving an exchange process between leader and subordinate, and a view of transformational leadership that allows for the development and transformation of people (Bass \& Avolio, 1990 and Meyer \& Botha, 2000). Transactional leaders are considered to enhance the subordinates' readiness to perform at expected levels, by offering rewards for acceptable performance, thus resulting in the desired outcomes defined by the leader (Bass \& Avolio, 1990 and Meyer \& Botha, 2000). Transactional leadership is known to be only moderately effective when practiced well (Bass, 1998). Transformational leaders, on the other hand, inspire their subordinates to adopt the organisational vision as their own, while attempting to heighten their values, concerns and developmental needs (Cacioppe, 1997) and to perform beyond expectations.

Although Burns (1978) initially conceived leaders to be either transformational or transactional, research has shown that transformational leadership is an extension and a more enlightened approach to transactional leadership (Pruijn \& Boucher, 1994). Bass and Avolio (1990) developed the Full Range Leadership Development Model, showing the development of transformational leadership from transactional leadership. This enabled them to develop the statistically validated Multifactor Leadership Questionnaire (MLQ), a full range assessment of both transactional and transformational leadership (Bass \& Avolio, 2000).

In the Full Range Leadership model transactional leadership is described by factors such as contingent reward and management-by-exception. Contingent reward involves an interaction between the leader and the follower in which the leader uses rewards, promises and praise to motivate followers to achieve performance levels contracted by both parties. Management-by-exception is defined as being either active or passive. Active Management-by-exception occurs when the leader monitors followers' performance for deviations from rules and standards, taking corrective action in anticipation of irregularities. In short, the leader intervenes in a follower's work when he is not putting forth the effort expected of him. In contrast, passive management-by-exception occurs when a leader waits passively for mistakes to occur, intervening only if standards are not met (Bass \& Avolio, 1997 and Mester, Visser \& Roodt, 2003).

Transformational leadership is characterised in the Full Range Leadership Development Model by four underlying dimensions, all of which are seen by Bass and Avolio (1994) as the most active and effective behaviours of leadership. These include idealised influence, intellectual stimulation, individualised consideration and inspirational motivation and are referred to as the 'Four l's' (Bass, 1990). Idealised influence (charisma) is behaviour that arouses strong follower emotions and identification with the leader (Yukl, 1998). Bass and Avolio (2000) further state that through such idealised influence, leaders become role models for their followers and are admired, respected and 
trusted. Inspirational motivation includes behaviour that motivates and inspires followers by communicating high expectations and expressing purposes in simple ways, which provides meaning and challenge to their followers' work (Bass, 1997). This inspirational motivation arouses individual and team spirit with enthusiasm and optimism (Yukl, 1998 and Bass \& Avolio, 2000). Individualised consideration is about paying attention to the needs of each individual and taking an interest in the follower beyond just what the organisation can get from the follower. Individualised consideration is about demonstrates a genuine concern for the "whole" person. It includes mentoring, support, encouragement and coaching of individual followers (Yukl, 1998). Intellectual stimulation involves leaders stimulating their followers' effort to be innovative and creative by questioning assumptions, reframing problems and approaching old situations in new ways (Bass \& Avolio, 2000).

Research (Bass \& Avolio, 1994; Kotter, 1988 and Meyer \& Botha, 2000) in organisational behaviour has identified transformational leadership as the most suitable for modern-day organisations. The current business environment requires this innovative kind of leadership style; a style that empowers employees and raises employee performance in an effort to improve organisational performance and continued existence (Kotter, 1988). In the South African context, Ristow, Amos and Staude (1999) found a positive relationship between transformational leadership and organisational effectiveness in the administration of cricket. Hayward, Davidson, Pascoe, Tasker, Amos and Pearse (2003) found transformational leadership to be more effective than transactional leadership in increasing employee performance. The research (Hayward et al., 2003) found a significant positive linear relationship between transformational leadership and employee performance but no significant linear relationship between transactional leadership and employee performance in a South African pharmaceutical organisation. Evidence has been gathered in South African retail and manufacturing sectors, as well in the armed forces of the United States, Canada and Germany that points towards the marginal impact transactional leaders have on the effectiveness of their subordinates in contrast to the strong, positive effects of transformational leaders (Brand, Heyl \& Maritz, 2000). Furthermore, in the Canadian financial industry it was found that transformational leadership is more strongly correlated with higher employee satisfaction and individual/organisational performance than transactional leadership (Meyer \& Botha, 2000). On the basis then of the literature, it could be proposed that transformational leadership as opposed to transactional leadership would be more effective in achieving higher levels of employee performance.

Besides transformational leadership, for Goleman (1995) and Stein and Book (2000) those leaders with greater emotional intelligence will be the more effective leaders. George (2000) suggests that emotional intelligence plays an important role in leadership effectiveness and proposes that the ability to understand and manage moods and emotions in oneself and in others theoretically contributes to the effectiveness of leaders. Goleman (1998) believes that emotions, properly managed, can drive trust, loyalty and commitment. In fact, research has shown that managers with high emotional intelligence can get results from employees that are beyond expectations (Cooper, 1997).

Goleman (1998) argues strongly that emotional intelligence is a requirement for successful leadership. George (2000) further suggested that leaders high in emotional intelligence will be able to use positive emotions to envision major improvements to the functioning of an organisation. Superior levels of emotional intelligence allow leaders to create a mutually agreed set of values to facilitate the development of employee potential in the organisation (Amos, Ristow \& Ristow, 2004). Additionally, leaders who exhibit an elevated level of emotional intelligence are likely to create a suitable context in which their subordinates are empowered to deliver superior performance (Amos et al., 2004). Given the literature, it would be expected that emotionally intelligent leaders would be more effective in achieving higher levels of employee performance than leaders lacking emotional intelligence.

Research by Palmer, Walls, Burgess and Stough (2001) indicates that transformational leadership is considered to be more emotion based than transactional leadership. These findings are consistent with work by Barling, Salter and Kelloway (2000) and Palmer et al. (2001) and support Goleman (1995) and Stein and Book's (2000) contention that effective leaders are emotionally intelligent.

Martinez (1997) refers to emotional intelligence as an array of cognitive skills, capabilities and competencies that influences a person's ability to cope with environmental demands and pressures, but there is no consensus in the literature on the exact nature of emotional intelligence. Different 
authors (Goleman, 1998; Bar-O, 2000 and Wolmarans, 2001) propose different factors in conceptualising the concept.

Goleman (1998) suggested that there are five critical pillars or competencies of emotional intelligence, these being self-awareness, self-regulation, self-motivation, social awareness and social skills. BarOn's (2000) non-cognitive model defines emotional intelligence as an array of non-cognitive capabilities, competencies and skills (intrapersonal, interpersonal, adaptability, stress management and mood) that influence one's ability to succeed in coping with environmental demands and pressures. Within the South African context, Wolmarans (2001) developed a statistically validated emotional intelligence assessment tool, the 360-Degree Emotional Competency Profiler (ECP). The ECP divides emotional intelligence into seven constituent competencies or clusters: self-motivation; self-esteem (and self-regard); self-management; change resilience; interpersonal relations; integration of 'head and heart'; and emotional literacy (Wolmarans \& Martins, 2001).

On the basis of the literature it can be hypothesised that transformational leaders are more effective in achieving higher levels of employee performance, that emotionally intelligent leaders would also be more effective in achieving higher levels of individual performance, that emotional intelligence and transformational leadership are associated and that leaders who are emotionally intelligent and demonstrate transformational leadership would be more effective in achieving higher levels of individual performance. The research hypotheses are developed in the next section which also outlines the research sample, data collection instruments, the research process and the methods of data analysis.

\section{RESEARCH METHODOLOGY}

As discussed in the sections above, it can be hypothesised that employee performance, leadership style and emotional intelligence are related. The purpose then of this research is to explore the relationship between employee performance, leadership style and emotional intelligence in the context of a South African parastatal.

\section{Research Hypotheses}

$\mathrm{H}_{\mathrm{a} 1}$ : There exists a significant, positive linear relationship between employee performance and transformational leadership.

$\mathrm{H}_{\mathrm{a} 2}$ : There exists a significant, positive linear relationship between employee performance and transactional leadership.

$\mathrm{H}_{\mathrm{a} 3}$ : There exists a significant, positive linear relationship between employee performance and emotional intelligence.

$\mathrm{H}_{\mathrm{a} 4:}$ There exists a significant positive linear relationship between employee performance and emotional intelligence and transactional leadership, that is when employee performance is regressed on emotional intelligence and transactional leadership the linear model will be significant, the partial slope coefficients will be significant and positive.

$\mathrm{H}_{\mathrm{a} 5}$ : There exists a significant positive linear relationship between employee performance and emotional intelligence and transformational leadership, that is when employee performance is regressed on emotional intelligence and transformational leadership the linear model will be significant, the partial slope coefficients will be significant and positive.

$\mathrm{H}_{\mathrm{a} 6 \text { : }}$ There exists a significant positive linear relationship between emotional intelligence and transactional leadership

$\mathrm{H}_{\mathrm{a} 7}$ : There exists a significant positive linear relationship between emotional intelligence and transformational leadership. 


\section{Research Population and Sample}

The research focused on the 180 supervisors (grouped as leaders for the purposes of this research) and their 1320 subordinates (grouped as raters) within a regional division of a South African parastatal. The sample comprised 160 of the 180 leaders and 800 of the 1320 raters. The 800 raters were chosen by the parastatal's regional Human Resource Management Department ensuring that the raters were in fact the subordinates of the sampled leaders and that there were at least two raters per leader.

\section{Research Instruments}

Two instruments were used in this research, namely the MLQ (Bass \& Avolio, 1997) and the ECP (Wolmarans \& Greeff, 2001). Employee performance data was provided by the parastatal from their performance management system. The performance management system requires managers to appraise each of their subordinates once a year. The performance appraisal consists of a number of key performance areas, with key performance indicators such as: key job outputs; people management (including supervision and leadership); interpersonal relationships and special projects. Each performance appraisal factor is measured using a scale of 1-5 where 1 is regarded as poor performance, 3 is the target (met performance standard) and 5 is exceptional performance. These scores are averaged, resulting in a total score out of 5 for each employee.

The MLQ (Bass \& Avolio, 1997) contains 45 statements relating to either transactional, transformational or non-transactional leadership factors. The respondent is required to judge how frequently the behaviour described in the statement is exhibited using a scale of 0 to 4 , with 0 indicating "not at all" and 4 indicating a "frequently if not always" rating (Bass \& Avolio, 1997). The MLQ consists of two versions, one for the leader to complete, and one for the raters of the leaders to complete. In this research, leader versions were completed by a supervisor in the sample, and between 2 and 5 rater versions were completed by the supervisor's subordinates, depending on the number of subordinates reporting to the relevant supervisor. For purposes of the analysis, data obtained from the leader and rater versions of the MLQ were pooled.

The MLQ has been tested for reliability and validity in a number of settings (Pruijn \& Boucher, 1994) through test-retest, internal consistency methods and alternative methods (Bass \& Avolio, 1997). The results of these test-retest analyses indicate that the components of transformational, transactional and non-transactional leadership are reliably measured by the MLQ (Bass \& Avolio, 1997). The factor structure of the MLQ has also been tested in the South African context by Ackerman, Scheepers, Lessing and Dannhauser (2000) with results yielding Cronbach alpha reliability coefficients of 0.944 , 0.736 and 0.803 for transformational leadership, transactional leadership and non-transactional leadership, confirming the factor structure of the MLQ developed by Bass and Avolio (1997). Research conducted by Botha (2001) in South Africa, yielded Cronbach's alpha reliability coefficients of $0.926,0.372$ and 0.660 for transformational, transactional and non-transactional leadership respectively, concluding that the MLQ instrument is a reliable measure of transformational leadership but a poor measure of transactional leadership. Similarly, Hayward et al. (2003) found the MLQ to be a reliable measure of transformational leadership but called into question the reliability of the instrument as a measure of transactional leadership.

Given the comprehensive nature of the instrument, its availability and that it was developed and tested within the South African context, the ECP (Wolmarans, 2001) was used to determine the emotional intelligence of the leaders within the organisation. The questionnaire contains 46 statements that identify and measure the key factors of emotional intelligence. Using a seven-point Likert scale $(1=$ never, 7 = always), the questionnaire covers factors such as emotional literacy, selfesteem/self-regard, self-management, self-motivation, change resilience, interpersonal relations and the integration of head and heart (Wolmarans, 2001).

A study based in South Africa (Palmer \& Jansen, 2004) found the ECP to be reliable with Cronbach alpha coefficients ranging from 0.851 to 0.981 . A factor analysis utilised by Wolmarans and Martins (2001) confirmed the factor structure of the ECP while findings by Coetzee (2005) provide support for the satisfactory psychometric properties of the ECP. 
The sampled leaders completed the questionnaire describing their own emotional intelligence, whilst their raters completed the same questionnaire regarding the emotional intelligence of their specific leader. The emotional intelligence data obtained from the leaders and the raters was pooled for purposes of the analysis.

\section{Data Collection Process}

The parastatal's region Human Resource Department distributed the questionnaires through the internal mailing system in an attempt to ensure that the respondents would receive the documents in the shortest possible time. The instruments, consisting of an MLQ and an ECP, accompanied by a covering letter were mailed to the leaders and raters individually. Respondents were requested to return the completed questionnaires via the internal mailing system to their relevant Human Resource practitioner who delivered them to the regional Human Resource Manager. The parastatal provided the 2004 performance rating scores of all the respondent raters/followers.

\section{Data Analysis}

Correlation analysis was used to test the significance of the relationship between the variable(s) identified in hypotheses 1, 2, 3, 6 and 7. Multiple regression analysis was used to test for the significance of the linear relationship between the variables identified as stipulated in hypotheses 4 and 5. The standard regression ANOVA/F-test was used to test the significance of the linear models. The significance of the independent variables partial slope parameters were ascertained using the standard/relevant t-tests. The reliability of the data was assessed using Cronbach alpha reliability coefficient.

\section{FINDINGS}

\section{Response Rate}

Of the 160 leaders surveyed, 89 completed the questionnaires (56\% response rate). Of the 800 raters, 326 completed the questionnaires (41\% response rate). The total sample size including leaders and their corresponding raters amounted to 415 employees ( $43 \%$ response rate).

\section{Reliability of Instruments}

In this research the Cronbach's alpha reliability coefficients for all the transformational leadership factors are acceptable (ranging from 0.686741 to 0.762428 ) with the reliability of transformational leadership being 0.920135 , which is good (Sekaran, 2000). The Cronbach alpha reliability coefficient of transactional leadership is poor at 0.389811 (Sekaran, 2000), which supports Botha's (2001) finding of 0.372 for the measure of transactional leadership.

The average Cronbach's alpha reliability coefficient for the ECP is 0.907199 , which is good (Sekaran, 2000). The Cronbach's alpha reliability coefficients for each factor deemed all seven emotional intelligence factors as good reliable measures (ranging from 0.871992 to 0.956451 ). Therefore, for this research, the ECP is considered a reliable measurement instrument of emotional intelligence. The findings of the research support those of Wolmarans and Martins (2001), Palmer and Jansen (2004) and Coetzee (2005) that the ECP is reliable.

\section{Hypotheses $\mathrm{H}_{\mathrm{a} 1}, \mathrm{H}_{\mathrm{a} 2}$ and $\mathrm{H}_{\mathrm{a} 3}$ : Employee Performance and Transformational Leadership, Transactional Leadership and Emotional Intelligence}

From Table 1 it is evident that there is a weak, non-significant, negative linear relationship between employee performance and transformational leadership $(r=-0.1159, n=276, p=0.054)$ at the $5 \%$ level of significance. The weak, negative linear relationship between employee performance and transactional leadership is significant $(r=-0.1970, n=276, p=0.001)$. The weak, negative linear relationship between employee performance and emotional intelligence is significant $(r=-0.1435, n=$ $276, p=0.017)$. 
Table 1: Correlations between employee performance scores and transformational leadership, transactional leadership and emotional intelligence

\begin{tabular}{|c|c|c|c|}
\hline & $\begin{array}{l}\text { Transformational } \\
\text { Leadership }\end{array}$ & Transactional Leadership & Emotional Intelligence \\
\hline $\begin{array}{l}\text { Employee } \\
\text { Performance }\end{array}$ & $\begin{array}{l}-0.1159 \\
{ }^{*} p=0.054\end{array}$ & $\begin{array}{l}-0.1970 \\
{ }^{*} p=0.001\end{array}$ & $\begin{array}{l}-0.1435 \\
{ }^{*} p=0.017\end{array}$ \\
\hline
\end{tabular}

\section{Hypothesis $\mathrm{H}_{\mathrm{a} 4}$ : Employee Performance, Emotional Intelligence and Transactional Leadership}

This hypothesis was tested by constructing the following linear model:

$P A=$ Intercept $+B_{1}{ }^{*}(E I)+B_{2}{ }^{*}(T A)+\varepsilon$

Where: $\quad P A=$ Employee Performance

$E I=$ Emotional Intelligence

$T A=$ Transactional Leadership

The results of regressing employee performance against emotional intelligence and transactional leadership can be found in Table 2. It is evident that this model is significant $(F(2,289)=5.1909, p<$ 0.006 ) with a very low coefficient of determination (Adjusted $R^{2}=0.02799713$ ), implying that only approximately $3 \%$ of the variation in employee performance is explained by the two independent variables in this model. The significant parameters are the intercept $(t=27.99425, d f=289, p=$ $0.000)$ and the transactional leadership parameter $(t=-2.68265, \mathrm{df}=289, \mathrm{p}=0.0077)$. The emotional intelligence parameter is not significant $(t=-0.47302, d f=289, p=0.6366)$ implying that emotional intelligence does not have a significant effect on the employee performance scores in this model.

Table 2: Summary of the linear regression model for hypothesis four: employee performance and emotionally intelligent transactional leadership

\begin{tabular}{|c|c|c|c|c|}
\hline \multicolumn{5}{|c|}{$\begin{array}{l}\text { Regression Summary for Dependent Variable: PA } R=0.18621913 R^{2}=0.03467756 \\
\text { Adjusted } R^{2}=0.02799713 F(2,289)=5.1909, p<0.00610\end{array}$} \\
\hline & B & Std.Err. & $\mathrm{t}(289)$ & $\mathrm{p}$-value \\
\hline Intercept & 3.799793 & 0.135735 & 27.99425 & 0.000000 \\
\hline $\begin{array}{l}\text { Emotional } \\
\text { Intelligence }\end{array}$ & -0.000246 & 0.000520 & -0.47302 & 0.636553 \\
\hline $\begin{array}{l}\text { Transactional } \\
\text { Leadership }\end{array}$ & -0.010440 & 0.003892 & -2.68265 & 0.007725 \\
\hline
\end{tabular}

Hypothesis $\mathrm{H}_{\mathrm{a} 5}$ : Employee Performance, Emotionally Intelligent and Transformational Leadership

This hypothesis was tested by constructing the following linear model:

$\mathrm{PA}=\operatorname{Intercept}+\beta_{1}{ }^{*}(\mathrm{EI})+\beta_{2}{ }^{*}(\mathrm{TF})+\varepsilon$

Where: $\quad P A=$ Employee Performance

$E I=$ Emotional Intelligence

TF $=$ Transformational Leadership

From Table 3 it can be seen that this model is not significant $(F(2,287)=2.8678, p<0.05845)$ and has a very low coefficient of determination (Adjusted $R^{2}=0.01276123$ ) implying that approximately $1 \%$ of the variation in employee performance is explained by emotional intelligence and transformational leadership. The only significant parameter is the intercept $(t=28.8, d f=287, p=0)$. The transformational leadership $(t=-0.54096, d f=287, p=0.588954)$ and the emotional intelligence parameters $(t=-1.36287, d f=287, p=0.173992)$ are not significant, implying that emotional 
intelligence and transformational leadership do not have a significant effect on the employee performance scores in this model.

Table 3: Summary of the Linear Regression Model for Hypothesis Five: Employee Performance and Emotionally Intelligent Transformational Leadership

\begin{tabular}{|c|c|c|c|c|}
\hline \multicolumn{5}{|c|}{$\begin{array}{l}\text { Regression Summary for Dependent Variable: PA } R=0.13997618 R^{2}=0.01959333 \text { Adjusted } \\
R^{2}=0.01276123 F(2,287)=2.8678 p<0.05845\end{array}$} \\
\hline & B & Std.Err. & $\mathrm{t}(287)$ & p-value \\
\hline Intercept & 3.752408 & 0.130289 & 28.80071 & 0.000000 \\
\hline $\begin{array}{l}\text { Emotional } \\
\text { Intelligence }\end{array}$ & -0.000892 & 0.000655 & -1.36287 & 0.173992 \\
\hline $\begin{array}{l}\text { Transformational } \\
\text { Leadership }\end{array}$ & -0.001308 & 0.002417 & -0.54096 & 0.588954 \\
\hline
\end{tabular}

\section{Hypothesis $\mathrm{H}_{\mathrm{a} 6}$ : Emotional Intelligence and Transactional Leadership}

Results revealed a relatively weak, but significant positive linear relationship between emotional intelligence and transactional leadership $(r=0.3962, n=382, p<0.0001)$.

\section{Hypothesis $\mathrm{H}_{\mathrm{a} 7}$ : Emotional Intelligence and Transformational Leadership}

A strong, significant $(r=0.6704, n=377, p<0.001)$ positive linear relationship exists between emotional intelligence and transformational leadership.

\section{DISCUSSION}

The findings of this research as presented in the previous section show that the ECP is a reliable measure of emotional intelligence and that while the MLQ is a reliable measure of transformational leadership, it is not a reliable measure of transactional leadership. Given the poor reliability of the transactional leadership measure, results relevant to the measure of transactional leadership in hypotheses 2, 4 and 6 are not discussed in this section.

This research revealed a weak, insignificant, negative linear relationship between employee performance and transformational leadership $(r=-0.1159, n=276, p=0.054)$ and a weak, significant, negative linear relationship between employee performance and emotional intelligence $(r=-0.1435$, $n=276, p=0.017)$. These findings don't support the conclusions drawn by authors such as Bass and Avolio (1997), who suggest that employee performance will be associated with high levels of transformational leadership. Nor do these results support research (Cooper, 1997) that suggests emotionally intelligent leaders can get results from employees that are beyond expectations since this research found a weak, significant linear relationship between employee performance and emotional intelligence $(r=-0.1435, n=276, p=0.017)$ that is negative in nature.

It was hypothesised that regressing employee performance against emotional intelligence and transformational leadership would result in a significant linear model in which these relevant partial slope parameters would be significant and positive and therefore provide good predictors of employee performance. This research does not confirm this expectation, as no significant linear relationship was found between employee performance, emotional intelligence and transformational leadership ( $F$ $(2,287)=2.8678, p=0.05845)$. These results indicate that emotional intelligence and transformational leadership have no significant effect on employee performance when considering this model. The independent variables slope parameters, emotional intelligence $(t=-1.36287, d f=287, p=0.173992)$ and transformational leadership $(t=-0.54096, d f=287, p=0.588954)$, were neither significant nor positive in this model. The negative partial slope coefficients, particularly in the case of transformational leadership contradict literature reviewed earlier in the paper, suggesting that emotionally intelligent leaders who adopt a transformational style will be more successful in achieving higher levels of employee performance. This model could however be attributed to the lack of variance of the parastatal performance appraisal scores, which made it difficult to differentiate between a good and a poor performance appraisal score. This could explain these findings. 
The results however of the correlation analysis of emotional intelligence and transformational leadership indicate that there is a very strong, significant positive linear relationship between emotional intelligence and transformational leadership $(r=0.6704, n=377, p<0.001)$. This finding is congruent with previous research by Goleman (1998), Brand, et al. (2000) and Palmer, et al. (2001).

Now that the findings of the research have been discussed, it is important that the limitations of the study be understood. These limitations are outlined below.

\section{Limitations of the Research}

The low reliability of the transactional leadership measure is a limitation which restricted utilisation of the measure in the study.

The research focused on a particular regional division of a South African parastatal and hence the results cannot be generalised to the entire parastatal or to other parastatals or organisations.

The lack of variance within the employee performance data made it difficult to differentiate clearly between a good and a poor performance appraisal score. It could be argued that the results of the regression analysis are biased by the lack of variance in employee performance data.

Given the findings and its limitations of this research, there is a need for further research. The following section makes suggestions as to further research opportunities.

\section{Suggestions for Further Research}

Parastatals play an important role in shaping the economy in South Africa. It is generally perceived that parastatals in the past have not performed sufficiently to ensure their continued existence, and thus are threatened by privatisation. There is a need for more research into the factors influencing individual, team and organisational performance of South African parastatals.

Further research needs to be conducted into the role of leadership in its various forms within organisational contexts, particularly the role of leadership in employee performance. However when dealing with employee performance, researchers need to be cautioned to the possible lack of variance within employee performance data and should take this into consideration during the design of the research. Further research should also be conducted into performance management systems, particularly focussing on the validity and reliability of the data produced, but also into their perceived accuracy and fairness by employees and managers. Managers in particular could be the focus of attention of research into the role of performance management systems in their jobs as managers (hindrance or facilitator) and into the issues and considerations of implementing performance management systems. Such research could prove valuable for the design and effective implementation of performance management systems. Also, research into the impact of organisational culture and values on the performance of individuals and the management of performance could prove valuable within a South African context.

The ECP has been tested in the South African environment, but exposure to the international arena could further benefit the instrument's validity. The development of a sufficient body of psychometric data would make further use of the ECP more viable through the provision of reliability and validity data. The design of more affordable instruments to measure emotional intelligence is also recommended, as it would stimulate further research.

This research did not take demographic variables into account in exploring differences in emotional intelligence, transactional leadership, transformational leadership and performance scores. Future research should be conducted comparing various homogenous demographic populations.

Future research may replicate the present work with other populations in various environments to contribute to a greater possibility of generalising findings. Such environments could include tertiary education institutions, the retail industry, the manufacturing industry and the political arena. 
Having explored future research opportunities, the attention of the paper now turns to the implications of the research study for management.

\section{MANAGERIAL IMPLICATIONS}

The performance of individuals is critical to the effectiveness of any organisation and needs to be managed. Any organisation requires an appropriate performance management system that is directly aligned to the strategic objectives of the business, ensuring that the strategic objectives of the business are translated into clear achievable objectives for each individual employee. The appraisal component of the system needs to be relevant and fair and should be tested by organisations for its continued reliability and validity. Any performance management system is only as effective as it is implemented. Managers play a crucial role not only in the implementation of a performance management system but in the leadership of desired performance outcomes of their subordinates. People are the key to organisational effectiveness and the key to the success of any business is being able to unleash the potential which resides within their human capital. To do this, organisations need to identify the leadership style most relevant to the achievement of their strategic performance indicators. The leadership needs to be aligned not only with these indicators but throughout the organisation to ensure that the organisation moves in the appropriate strategic direction to achieve its performance indicators. In the final instance though, organisations should base the decision to introduce an appropriate leadership style on valid and reliable empirical research within their own particular organisational context.

\section{CONCLUSION}

The aim of this research was to examine the relationship between employee performance, leadership and emotional intelligence in a South African parastatal.

The results of the research show that there is a weak, non-significant, negative linear relationship between employee performance and transformational leadership. In addition, the linear regression analysis of the research produced differing results from the expectation of emotional intelligence and transformational leadership explaining variance in employee performance. It was however found that there is a very strong, significant linear positive relationship between emotional intelligence and transformational leadership, confirming a contention that transformational leaders are more emotionally intelligent that transactional leaders.

This research draws attention to the need for further research to clarify the leadership necessary to achieve high levels of employee performance within the relevant South African parastatal.

\section{REFERENCES}

Ackerman CP, Scheepers JM, Lessing BC \& Dannhauser Z. 2000. Die Faktorstruktuur van Bass se Veelfaktor Leierskapvraelys in die Suid-Afrikaanse Konteks. Journal of Industrial Psychology, 26(2):58-65.

Adam C, Cavendish W \& Mistry P. 1992. Adjusting Privatisation. London: Heinemann.

Amos TL, Ristow A \& Ristow L. 2004. Human Resource Management. $2^{\text {nd }}$ Ed. Lansdowne: Juta and Co Ltd.

Barling J, Salter F \& Kelloway EK. 2000. Transformational leadership and El: an exploratory study. Learnership \& Organizational Development Journal, 21(3):157-161.

Bar-on R. 1996. The Emotional Quotient Inventory (EQ-i): A Test of Emotional Intelligence. Toronto: Multi-Health Systems.

Bar-on R. 2000. Emotional and Social Intelligence. In Bar-On R \& Parker JDA (eds) The Handbook of Emotional Intelligence. San Francisco: Jossey-Bass. 
Bass BM. 1990. Bass and Stogdill's handbook of leadership: Theory, Research and Managerial applications. New York: Free Press.

Bass BM. 1997. Concepts of Leadership. In Vecchio RP (ed) Leadership: Understanding the Dynamics of Power and Influence in Organizations. Notre Dame: University of Notre Dame Press.

Bass BM. 1998. Transformational Leadership: Industrial, Military, and Educational Impact. Mahwah, New Jersey: Lawrence Erlbaum and Associates.

Bass BM \& Avolio BJ. 1990. Developing Transformational Leadership: 1992 and Beyond. Journal of European Industrial Training, 14(5):21-27.

Bass BM \& Avolio BJ. 1994. Improving Organizational Effectiveness: Through Transformational Leadership. Thousand Oaks: Sage Publications Inc.

Bass BM \& Avolio BJ. 1997. Full Range Leadership Development: Manual for the Multifactor Leadership Questionnaire. Redwood City: Mind Garden Inc.

Bass BM \& Avolio BJ. 2000. Multifactor Leadership Questionnaire. Redwood City: Mind Garden Inc.

Botha J. 2001. The Relationship between Leadership, Internal Quality, and Customer Satisfaction Levels of Dealerships in a South African Motor Vehicle Organisation. Unpublished Masters Thesis. Grahamstown: Rhodes University.

Brand C, Heyl G \& Maritz D. 2000. Leadership In Meyer M \& Botha E (eds) Organisational Development and Transformation in South Africa. Durban: Butterworths.

Burns JM. 1978. Leadership. New York: Harper and Row.

Cacioppe R. 1997. Leadership Moment by Moment. Leadership and Organisational Development Journal, 18(7):335-345.

Charlton GD. 1993. Leadership: The human race. Cape Town: Juta.

Coetzee M. 2005. Organisational report: 360-Degree Emotional Competency Profiler Results. Unpublished report. Pretoria: University of South Africa.

Cooper RK. 1997. Applying emotional intelligence in the workplace. Training and Development, 51(12):31-38.

Cullen K, Gilmour L \& Holmes A. 2005. Collins Dictionary and Thesaurus. London: Harper Collins.

George JM. 2000. Emotions \& leadership: the role of El. Human Relations, 53(12):1027-1041.

Goleman D. 1995. Emotional Intelligence. New York: Bantam.

Goleman D. 1998. Working with Emotional Intelligence. New York: Bantam.

Hayward BA, Davidson AJ, Pascoe JB, Tasker ML, Amos TL \& Pearse NJ. 2003. The Relationship between Leadership and Employee Performance in a South African Pharmaceutical Company. Paper presented at the Society for Industrial and Organisational Psychology 6th Annual Conference, 25-27 June 2003, Sandton, Johannesburg.

Kotter JP. 1988. The smarts that count. HR Magazine, 42(11):72-78.

Meyer M \& Botha E. 2000. Organisation Development and Transformation in South Africa. Durban: Butterworths. 
Mester C, Visser D \& Roodt G. 2003. Leadership Style and its Relation to Employee Attitudes and Behaviour. SA Journal of Industrial Psychology, 29(2):72-80.

Nwankwo S \& Richards DC. 2001. Privatization: The myth of free market orthodoxy in sub-Saharan Africa. The International Journal of Public Sector Management, 14(2):165-179.

Palmer PN \& Jansen CA. 2004. Emotional Intelligence as an Important Attribute of Transformational Leadership. Paper Presented at the Southern African Institute of Management Scientist Annual Conference, 17-29 September 2004, Cape Town.

Palmer B, Walls M, Burgess Z \& Stough C. 2001. Emotional intelligence and effective leadership. Leadership \& Organization Development Journal, 22(20):1-7.

Personal Communication. 2004. Southern Region Human Resource Manager. The Parastatal, East London. April - December.

Pruijn GHJ \& Boucher RL. 1994. The Relationship of Transactional and Transformational Leadership to the Organisational Effectiveness of the Dutch National Sports Organisations. European Journal of Sports Management, 1:72-87.

Ristow A, Amos T \& Staude G. 1999. Transformational leadership and organisational effectiveness in the administration of cricket in South Africa. South African Journal of Business Management, $30(1): 1-5$.

Sekaran U. 2000. Research Methods for Business $.3^{\text {rd }}$ Ed. New York: Hermitage Publishing Services.

Stein SJ \& Book HE. 2000. The EQ Edge: EQ and Your Success. Toronto: Stoddart Publishing.

Wolmarans IS. 2001. Emotional Competencies of the Future. Unpublished paper. Johannesburg: Learning Link International.

Wolmarans IS \& Greeff A. 2001. 360-Degree Emotional Competency Profiler. Johannesburg: Learning Link International.

Wolmarans IS \& Martins N. 2001. The 360-Degree Emotional Competency Profiler. Unpublished manual. Johannesburg: Organisational Diagnostics and Learning Link International.

Yukl G. 1998. Leadership in Organisations. Englewood Cliffs: Prentice-Hall. 